\title{
Biochemical properties of an extracellular $\beta$-D-fructofuranosidase II produced by Aspergillus phoenicis under Solid-Sate Fermentation using soy bran as substrate
}

\author{
Cynthia Barbosa Rustiguel ${ }^{1}$ - Arthur Henrique Cavalcanti de Oliveira ${ }^{2}$ Héctor Francisco Terenzi $^{1}$ \\ João Atílio Jorge ${ }^{1} \cdot$ Luis Henrique Souza Guimarães ${ }^{1} \square$ \\ 1 Departamento de Biologia, Faculdade de Filosofia, Ciências e Letras, Ribeirão Preto, Universidade de São Paulo, São Paulo, \\ Brasil \\ 2 Departamento de Química, Faculdade de Filosofia, Ciências e Letras,Ribeirão Preto, Universidade de São Paulo, São Paulo, \\ Brasil
}

$\triangle$ Corresponding author: Ihguimaraes@ffclrp.usp.br

Received September 9, 2010 / Accepted December 20, 2010

Published online: March 15, 2011

(C) 2011 by Pontificia Universidad Católica de Valparaíso, Chile

\begin{abstract}
The filamentous fungus $A$. phoenicis produced high levels of $\beta$-D-fructofuranosidase (FFase) when grown for 72 hrs under Solid-State Fermentation (SSF), using soy bran moistened with tap water $(1: 0.5 \mathrm{w} / \mathrm{v})$ as substrate/carbon source. Two isoforms (I and II) were obtained, and FFase II was purified 18-fold to apparent homogeneity with $14 \%$ recovery. The native molecular mass of the glycoprotein (12\% of carbohydrate content) was $158.5 \mathrm{kDa}$ with two subunits of $85 \mathrm{kDa}$ estimated by SDS-PAGE. Optima of temperature and $\mathrm{pH}$ were $55^{\circ} \mathrm{C}$ and 4.5 . The enzyme was stable for more than $1 \mathrm{hr}$ at $50^{\circ} \mathrm{C}$ and was also stable in a pH range from 7.0 to 8.0 . FFase II retained $80 \%$ of activity after storage at $4^{\circ} \mathrm{C}$ by $200 \mathrm{hrs}$. Dichroism analysis showed the presence of random and $\beta$-sheet structure. A. phoenicis FFase II was activated by $\mathrm{Mn}^{2+}, \mathrm{Mg}^{2+}$ and $\mathrm{Co}^{2+}$, and inhibited by $\mathrm{Cu}^{2+}, \mathrm{Hg}^{2+}$ and EDTA. The enzyme hydrolyzed sucrose, inulin and raffinose. $\mathrm{K}_{d}$ and $\mathrm{V}_{\max }$ values were $18 \mathrm{mM}$ and $189 \mathrm{U} / \mathrm{mg}$ protein using sucrose as substrate.
\end{abstract}

Keywords: agroindustrial substrate, Aspergillus, $\beta$-D-fructofuranosidase, solid state fermentation, sucrose

\section{INTRODUCTION}

Enzymes with biotechnological potential, such as $\beta$-D-fructofuranosidases, can be produced by many organisms, especially microorganisms like bacteria, yeast and filamentous fungi. These enzymes are grouped in the $\mathrm{GH}-32$ family of glycosidases that hydrolyze the alpha-beta linkage of carbohydrates with fructofurasyl residue, such as sucrose, producing a mixture of D-glucose and D-fructose known as invert sugar (Alberto et al. 2004). This catalytic property has attracted the attention of several industrial sectors, like as confectionery, food and beverage industries, which use fructose for formulation of candies, chocolates and soft drinks. Fructose is a monosaccharide with higher sweetener power and non crystallisable. In addition, it can be also used by diabetic people. Fructofuranosidases with fructosyltransferase activity can be used to produce fructooligosaccharides (FOS), as 1-kestose and 1nystose, prebiotic substances that have important functional properties (Toledo et al. 2004; Maiorano et al. 2008). Microorganisms have been used to produce these enzymes, especially filamentous fungi such as Aspergillus niger (Rubio and Navarro, 2006), Aspergillus japonicus (Cheng et al. 2005), Aspergillus ochraceus (Guimarães et al. 2007), Aspergillus niveus (Guimarães et al. 2009) and Cladosporium cladosporioides (Almeida et al. 2005), among others. The production of $\beta$-Dfructofuranosidase by fungi is conducted under Submerged Fermentation (SbmF) or under Solid State Fermentation (SSF) (Romero-Gómez et al. 2000; Aranda et al. 2006). SSF has several advantages over SbmF, such as the similarity with natural conditions found by microorganisms, use of cheap substrates, as for instance agroindustrial residues and products, and higher levels of production. In 
addition, the water activity in SSF is an important factor for microorganism grown and enzyme production. Despite these positive facts, the control of culture conditions such as temperature and $\mathrm{pH}$ is very difficult. Hence, our aim was to characterize the $\beta$-D-fructofuranosidase II produced by Aspergillus phoenicis in SSF at high levels using agroindustrial products as alternative low cost substrate/carbon source. Basic information, as the biochemical properties, is important to determine the best conditions for enzyme application in the industrial process.

\section{MATERIALS AND METHODS}

\section{Microorganism and culture condition}

Aspergillus phoenicis (= Aspergillus saitoi) was isolated from soil and identified by André Tosello Foundation, Campinas, SP, Brasil. The microorganism was maintained on slants of PDA medium (Acumedia) at $40^{\circ} \mathrm{C}$ for 7 days, and then stored at $4^{\circ} \mathrm{C}$. Solid-State Fermentation (SSF) cultures were carried out using different agroindustrial products as carbon source/substrate in $125 \mathrm{~mL}$ Erlenmeyer flasks with $8 \mathrm{~g}$ of substrate humidified with water or SR (Rizzatti et al. 2001), Khanna (Khanna et al. 1995) or Vogel (Vogel, 1964) salt solutions, in the proportion 1:1 (w/v), plugged with cotton and autoclaved for $20 \mathrm{~min}$. The media were inoculated with $2 \mathrm{~mL}$ of a spore suspension $\left(10^{5} \mathrm{spores} / \mathrm{mL}\right)$ and maintained at $40^{\circ} \mathrm{C}$ at relative humidity of $70 \%$ monitored with a digital thermo-hygrometer.

\section{Crude extract and enzymatic assay}

$50 \mathrm{~mL}$ of cold distilled water was added into SSF culture flasks and submitted to agitation for $30 \mathrm{~min}$ using a magnetic stirrer, at $4^{\circ} \mathrm{C}$. Then, the suspension was vacuum filtered through gauze. The obtained filtrate was centrifuged $(23000 \mathrm{~g})$ to remove particles and the clear supernatant was the source of crude $\beta$-D-fructofuranosidase activity.

$\beta$-D-fructofuranosidase activity was determined using $1 \%$ sucrose as substrate in sodium acetate buffer, $100 \mathrm{mM}, \mathrm{pH}$ 4.5. The reaction mixture was composed by $200 \mu \mathrm{L}$ of buffer containing substrate and $200 \mu \mathrm{L}$ of diluted enzyme. The reaction was carried out at pre-determined times and temperatures $\left(30^{\circ} \mathrm{C}-75^{\circ} \mathrm{C}\right)$. The reactions were stopped by addition of 3,5-Dinitro-salicylic acid (DNS) and the reducing sugars were quantified according to Miller (1959), at $540 \mathrm{~nm}$. One unit of enzyme activity (U) was defined as the amount of enzyme that releases $1 \mu \mathrm{mol}$ of glucose per min under the assay conditions. The values of enzymatic activity were expressed as $\mathrm{U} / \mathrm{g}$ of substrate.

\section{Protein and carbohydrate quantification}

Protein was quantified according to Lowry et al. (1951) using bovine serum albumin (BSA) as standard. The carbohydrate content in the purified enzyme was determined according to Dubois et al. (1956), using mannose as standard.
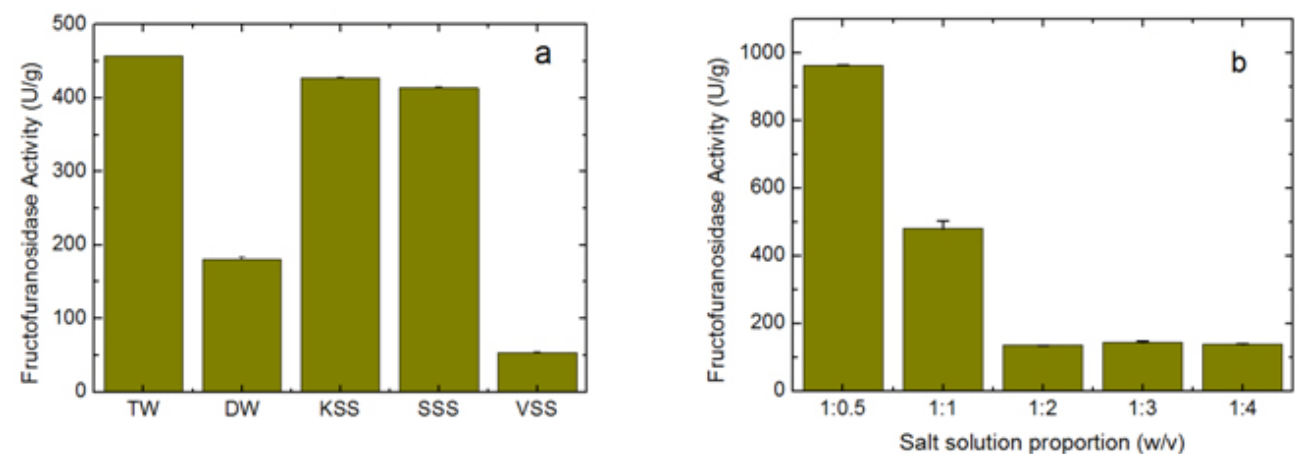

Fig. 1 Influence of different salt solutions (a), and proportion of tap water (b) in the production of $\beta$-DFructofuranosidases by $\boldsymbol{A}$. phoenicis under SSF with soy bran as substrate. TW: tap water; DW: distilled water; KSS: Khanna salt solution; SSS: SR salt solution; VSS: Vogel salt solution. 


\section{Purification}

The crude extract was loaded into a DEAE-Cellulose chromatographic column $(10.0 \mathrm{~cm} \times 2.0 \mathrm{~cm})$ equilibrated with $10 \mathrm{mM}$ Tris(hydroxymethyl)-aminomethan (TRIS)-HCl buffer, $\mathrm{pH} 7.5$ (buffer A) and eluted with a $\mathrm{NaCl}$ linear gradient $(0-1 \mathrm{M} \mathrm{NaCl})$ in the same buffer. $3 \mathrm{~mL}$ fractions were collected at a flow rate of $1.9 \mathrm{~mL} / \mathrm{min}$ and two enzymatic forms $\beta$-D-fructofuranosidase (FFase I and II) were obtained. The fractions with FFase II activity were pooled, dialyzed overnight against distilled water at $4^{\circ} \mathrm{C}$, lyophilized, ressuspended in $50 \mathrm{mM}$ TRIS-HCl buffer, $\mathrm{pH} 7.5$ containing of $50 \mathrm{mM} \mathrm{NaCl}$ (buffer B) and loaded into a gel sieving Sephacryl S-200 column $(80.0 \mathrm{~cm} \times 2.0 \mathrm{~cm})$, equilibrated in the same buffer $(B)$ and maintained in a cold room at $4^{\circ} \mathrm{C} .1 \mathrm{~mL}$ fractions were collected at a flow rate of 0.38 $\mathrm{mL} / \mathrm{min}$. The fractions with activity were pooled, dialyzed as mentioned above and used for biochemical characterization.

Table 1. Production of $\beta$-D-fructofuranosidases by $A$. phoenicis under SSF with different substrates.

\begin{tabular}{cc}
\hline Substrates & Activity (U/g) \\
Sugar cane bagasse (SC) & $18.67 \pm 0.00$ \\
Soy bran (SB) & $470.55 \pm 1.42$ \\
Wheat bran (WB) & $35.27 \pm 1.02$ \\
Crushed corn (CC) & $3.88 \pm 0.08$ \\
Rice straw (RS) & $78.18 \pm 0.73$ \\
SB + SC & $27.26 \pm 0.23$ \\
SB + WB & $566.43 \pm 2.72$ \\
SB + CC & $456.45 \pm 1.36$ \\
SB + RS & $64.79 \pm 1.02$ \\
\hline
\end{tabular}

Data are the means \pm SD of at least 3 different cultures.

\section{Molecular mass determination}

The purified FFase II was submitted to denaturing electrophoresis (7\% SDS-PAGE) performed according to Laemmli (1970) $(120 \mathrm{~V} ; 40 \mathrm{~m} \AA$ ) and the protein bands were stained by silver nitrate (Blum et al. 1987). Molecular mass makers $\left(\right.$ Sigma $\left.^{\circledR}\right)$ were $\alpha$-macroglobulin (168 kDa), $\beta$-galactosidase (112 $\mathrm{kDa})$, lactoferrin $(91 \mathrm{kDa})$, pyruvate kinase $(67 \mathrm{kDa})$ and dehydrogenase (36 kDa). The native molecular mass was estimated by gel filtration using Sephacryl S-200 chromatographic column according to the conditions mentioned above. It was used alcohol dehydrogenase (150 kDa), BSA (66 $\mathrm{kDa})$, egg albumin $(43 \mathrm{kDa})$ and carbonic anhydrase $(29 \mathrm{kDa})$, obtained from Sigma ${ }^{\circledR}$, as molecular mass makers.

\section{Thermal and pH stabilities}

The purified enzyme was incubated for $1 \mathrm{hr}$ at $50^{\circ} \mathrm{C}$ or $60^{\circ} \mathrm{C}$, and also at different $\mathrm{pH}$ values using 100 mM sodium acetate buffer ( $\mathrm{pH} 3.5$ to 4.5), $50 \mathrm{mM}$ Mes buffer ( $\mathrm{pH} 6.0$ ), $50 \mathrm{mM}$ Tris-HCl buffer (pH 7.0 to 8.0 ) and $50 \mathrm{mM}$ CAPS buffer ( $\mathrm{pH} 9.0$ to 10.0) and then assayed to determine the residual $\beta$-Dfructofuranosidase activity. The influence of the conditions of storage $\left(-20^{\circ} \mathrm{C}, 4^{\circ} \mathrm{C}\right.$ and $\left.27^{\circ} \mathrm{C}\right)$ at different periods (until $200 \mathrm{hrs}$ ) was also analyzed.

\section{Circular dichroism}

UV circular dichroism spectra (190-250nm) were measured with a JASCO 810 spectropolarimeter (JASCO Inc., Tokyo, Japan) using $1 \mathrm{~mm}$-pathlength cuvettes at a protein concentration of $500 \mu \mathrm{gL}^{-1}$. All measurements were performed in $20 \mathrm{mM}$ phosphate/citrate buffer ( $\mathrm{pH} \mathrm{5.5)}$ at $25^{\circ} \mathrm{C}$. A total of ten spectra were collected, which after averaging were corrected by subtraction of a buffer blank. 

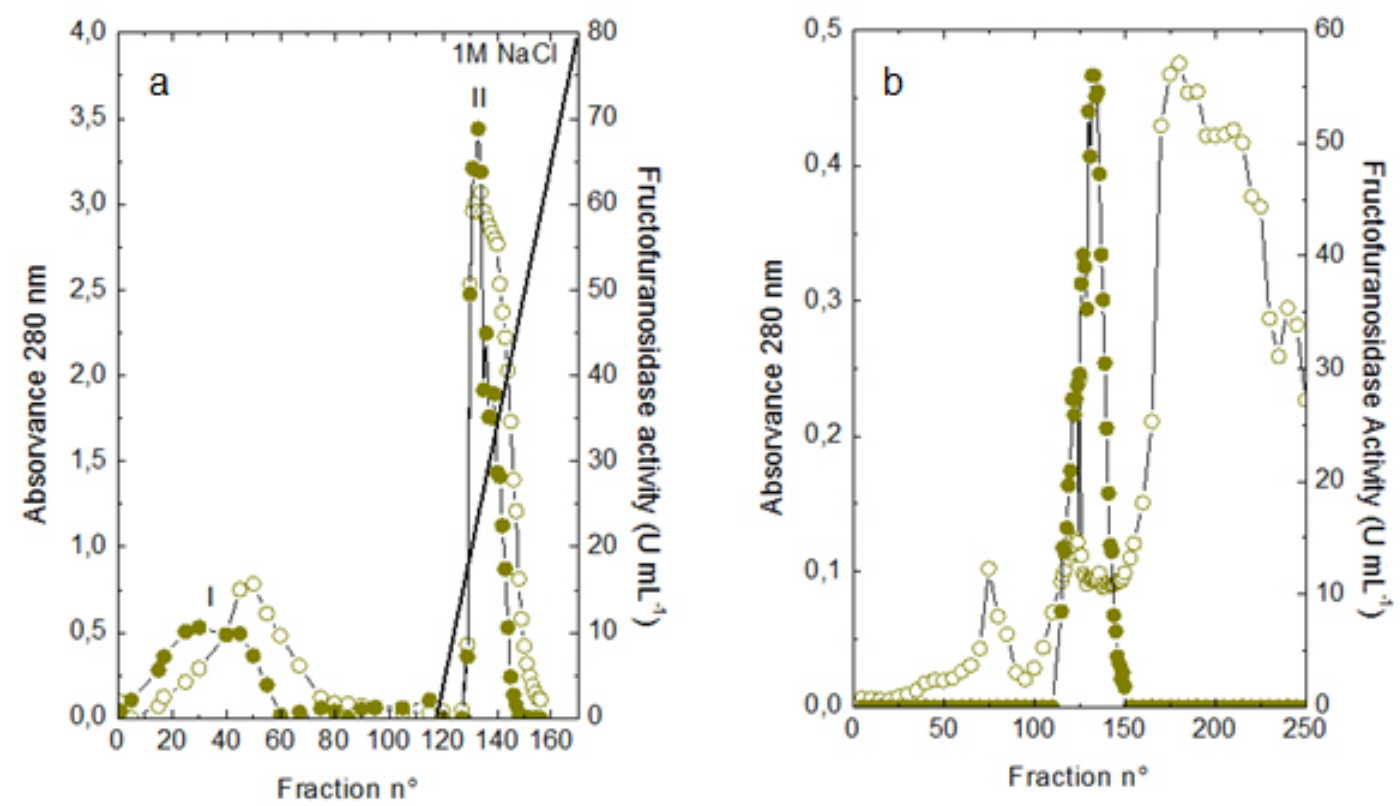

Fig. 2 DEAE-Cellulose (a) and Sephacryl S-200 (b) chromatographic profiles for extracellular $\beta$-Dfructofuranosidases and FFase II, respectively, produced by A. phoenicis under SSF. Symbols: ( ) absorbance $280 \mathrm{~nm} ;(\bullet) \beta$-D-Fructofuranosidase activity.

\section{Determination of kinetic parameters}

The kinetic parameters as $\mathrm{V}_{\max }, \mathrm{K}_{\mathrm{d}}$ and $\mathrm{V}_{\max } / \mathrm{K}_{\mathrm{d}}$ (catalytic efficiency) were determined with sucrose as substrate (from $0.5 \mathrm{mM}$ to $300 \mathrm{mM}$ ) using the Lineweaver-Burk representation and the data were processed by Sigraf software (Leone et al. 1995).

\section{Hydrolysis products analysis}

The purified enzyme was incubated with $20 \%$ sucrose as substrate in $100 \mathrm{mM}$ sodium acetate buffer, $\mathrm{pH} 4.5$ at $60^{\circ} \mathrm{C}$ for $24 \mathrm{hrs}$. Samples were withdrawn at 0, 2, 12 and $24 \mathrm{hrs}$ and submitted to thin layer chromatography analysis (TLC) $(20 \times 10 \mathrm{~cm})$ using butanol:ethanol:water $(5: 3: 2$; v/v/v) as mobile phase. After the run, the plates were dried at room temperature, sprayed with a solution of $0.2 \%$ orcinol in sulfuric acid and methanol $(1: 9 ; \mathrm{v} / \mathrm{v})$ and heated at $100^{\circ} \mathrm{C}$ for visualization of the dyed spots. Five $\mu \mathrm{L}$ of $1 \%$ sucrose, $1 \%$ glucose and $1 \%$ fructose were used as standards.

\section{RESULTS AND DISCUSSION}

\section{Production and purification of $\beta-D$-fructofuranosidase}

A. phoenicis produced high levels of $\beta$-D-fructufuranosidase (470.5 U/g of substrate) under SSF using soy bran as carbon source/ substrate (Table 1). However, a mixture of soy bran and wheat bran

Table 2. Purification of $\beta$-D-fructofuranosidases produced by fungus $A$. phoenicis under SSF.

\begin{tabular}{cccccc}
\hline Steps & Activity & Protein & Specific activity & Yield & Purification \\
& $($ Total $U)$ & $($ Total $\mathrm{mg})$ & $(\mathrm{U} / \mathrm{mg}$ prot $)$ & $(\%)$ & $(\mathrm{X})$ \\
Crude extract & $3,865.70$ & 223.2 & 17.31 & 100 & 1 \\
DEAE Celulose & $1,942.31$ & 15.48 & 125.47 & 50.24 & 7.24 \\
Sephacryl S200 & 559.02 & 1.72 & 325.01 & 14.46 & 18.77 \\
\hline
\end{tabular}


increased by $20 \%$ the amount of enzyme. Probably, soy bran offered additional nutrients improving the fungus development and also increasing the production of the enzyme. High levels of $\beta-D-$ fructufuranosidase by $A$. phoenicis were also obtained under submerged fermentation, but using wheat bran as carbon source (Rustiguel et al. 2010). The use of agroindustrial products or residues for SSF is an interesting alternative because it lowers cost for industries in the process of production of biomolecules, high recovery of the main product and availability of great variety of substrates. In addition, SSF reproduces the conditions found by microorganisms in natural environments, although it is difficult to control the cultivation conditions. Considering soy bran as substrate, the maximal production was obtained after $72 \mathrm{hrs}$ of growth using 1:0.5 (w/v) tap water to humidify this substrate (Figure 1). The production under such conditions was 30-times higher than that obtained under SbmF (Rustiguel et al. 2010). According to Ashokkumar et al. (2001) the maximal production of $\beta$-Dfructofuranosidase by Aspergillus niger under SSF was also obtained after $72 \mathrm{hrs}$. Tap water may have salts that can contribute to the fungus development, which were not present in the other tested solutions. If the humidity of the medium is increased, the $\beta$-D-fructofuranosidase production diminished, perhaps due to lower aeration in the culture medium.

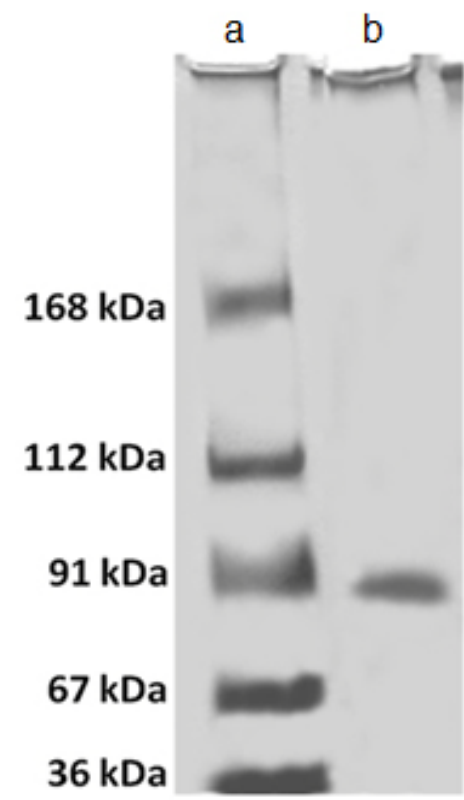

Fig. 3 Denaturing electrophoresis (7\% SDS-PAGE) for the purified extracellular $\beta$-D-fructofuranosidase (FFase II) produced by $A$. phoenicis under SSF stained by silver: Molecular makers (a): $\alpha$-macroglobulin (168 kDa), $\beta$-galactosidase (112 kDa), lactoferrin $(91 \mathrm{kDa})$, pyruvate kinase $(67 \mathrm{kDa})$ and Dehydrogenase $(36$ kDa).

The $\beta$-D-fructofuranosidase activity produced by $A$. phoenicis in SSF was resolved by DEAE-Cellulose chromatography into two enzymatic forms (FFase I and FFase II) (Figure 2a). FFase I did not interact with the resin and FFase II was eluted with $271 \mathrm{mM}$ of $\mathrm{NaCl}$. FFase II was submitted to Sephacryl S200 chromatography, where it was eluted as a single peak (Figure 2b). After these procedures FFase II was purified 18 -fold with a recovery of about $15 \%$ (Table 2). Interestingly, under SbmF, only a single enzymatic form was obtained, which interacted with DEAE-Cellulose (Rustiguel et al. 2010). Thus, the conditions used in SSF were able to permit the production of another $\beta$-D-fructofuranosidase form. Multiple $\beta$-D-fructofuranosidases forms have been reported for Aureobasidium pullulans (Yoshikawa et al. 2006). Aspergillus oryzae KB was able to produce two enzymatic forms, one preferentially produced at high sucrose concentration, and another at low sucrose concentration (Kurakake et al. 2008).

FFase II was a glycoprotein with native molecular mass of $158.5 \mathrm{kDa}$ and $12.23 \%$ of carbohydrate content, and constituted of two subunits of $85.11 \mathrm{kDa}$, according to denaturing electrophoresis $(7.0 \%$ SDS-PAGE) (Figure 3). Homodimeric $\beta$-D-fructofuranosidases were also observed for $A$. ochraceus with two subunits of $79 \mathrm{kDa}$ (Guimarães et al. 2007) and for R. glutinis, with subunits of $47 \mathrm{kDa}$ (Rubio et al. 2002). For future biochemical characterization, the FFase I should be purified. 
Table 3. Effect of several compounds on the $\beta$-fructofuranosidase activity.

\begin{tabular}{ccc}
\hline & \multicolumn{2}{c|}{ Relative fructofuranosidase activity (\%) } \\
\hline Compounds & $1 \mathrm{mM}$ & $10 \mathrm{mM}$ \\
\hline Without & 100.00 & 100.00 \\
$\mathrm{AlCl}_{3}$ & $113.45 \pm 7.62$ & $82.19 \pm 4.64$ \\
$\mathrm{BaCl}_{2}$ & $104.07 \pm 6.40$ & $93.02 \pm 1.46$ \\
$\mathrm{CaCl}_{2}$ & $115.67 \pm 4.05$ & $104.04 \pm 2.99$ \\
$\mathrm{CoCl}_{2}$ & $123.31 \pm 1.08$ & $92.79 \pm 3.45$ \\
$\mathrm{CuCl}_{2}$ & $73.39 \pm 4.67$ & $44.54 \pm 4.23$ \\
$\mathrm{EDTA}$ & $84.59 \pm 2.26$ & $38.06 \pm 0.05$ \\
$\mathrm{HgCl}_{2}$ & $67.20 \pm 3.26$ & $3.38 \pm 1.55$ \\
$\mathrm{MgCl}_{2}$ & $124.67 \pm 9.96$ & $76.58 \pm 0.66$ \\
$\mathrm{MnCl}_{2}$ & $130.00 \pm 1.37$ & $168.90 \pm 2.20$ \\
$\mathrm{ZnCl}$ & $99.39 \pm 6.87$ & $51.79 \pm 0,00$ \\
\hline
\end{tabular}

Data are the means $\pm S D$ of at least 3 different experiments.

\section{Influence of temperature and $\mathrm{pH}$}

The optimum temperature of FFase II produced by $A$. phoenicis under SSF was $55^{\circ} \mathrm{C}$ (Figure $4 a$ ) and its optimum $\mathrm{pH}$ was 4.5 (Figure $4 \mathrm{~b}$ ). This temperature optimum was higher than that reported for the enzyme from Bifidobacterium infantis ATCC 15697 (Warchol et al. 2002), Lactobacillus reuteri (Ginés et al. 2000), Fusarium solani (Bhatti et al. 2006), Aspergillus niger IMI303386 (Nguyen et al. 2005) and A. oryzae KB (Kurakake et al. 2008), and similar with that of the $\beta$-fructofuranosidases from Aspergillus niger ATCC 20611 and Aureobasidium sp. ATCC 20524 (Yoshikawa et al. 2007). The optimum pH was similar to those of the enzymes from Aspergillus ochraceus (Guimarães et al. 2007) and Aspergillus niveus (Guimarães et al. 2009). The enzyme was stable at $50^{\circ} \mathrm{C}$, and exhibited a half-life of 13 min at $60^{\circ} \mathrm{C}$ in aqueous solution (Figure 4c). The enzyme was also stable for more than $1 \mathrm{hr}$ at $\mathrm{pH} 7.0$ and 8.0 (Figure 4d), differing from the invertase from Rodotorula glutinis, which was stable between $20^{\circ} \mathrm{C}$ and $60^{\circ} \mathrm{C}$, and at $\mathrm{pH}$ from 2.6 to 5.5 for $30 \mathrm{~min}$ (Rubio et al. 2002). In addition, the FFase II from $A$. phoenicis retained full activity after $75 \mathrm{hrs}$ at $4^{\circ} \mathrm{C}$, and remained $80 \%$ active after $200 \mathrm{hrs}$ at this temperature and also at $-20^{\circ} \mathrm{C}$. The enzyme exhibited a $\mathrm{t}_{50}$ of $200 \mathrm{hrs}$ at $27^{\circ} \mathrm{C}$ (Figure 5 ). The condition of storage is another point that needs to be considered for industrial application, since products with good stability are preferred.

\section{Influence of ions and EDTA in the FFase II activity}

FFase II activity was enhanced by $1 \mathrm{mM}$ of several divalent ions such as $\mathrm{Mn}^{2+}(30 \%), \mathrm{Mg}^{2+}(24 \%)$ and $\mathrm{Co}^{2+}(23 \%)$, among others, and inhibited around of $16-33 \%$ by $\mathrm{Cu}^{2+}, \mathrm{Hg}^{2+}$ and EDTA (Table 3). However, at $10 \mathrm{mM}$ concentration of these compounds, significant activation was only observed in the presence of $\mathrm{Mn}^{2+}(68 \%) . \mathrm{Hg}^{2+}$ inhibited drastically the FFase II activity. The enzyme produced by $R$. glutinis also was enhanced by $\mathrm{Mg}^{2+}$ and $\mathrm{Co}^{2+}$ (Rubio et al. 2002). $\mathrm{Hg}^{2+}$ and $\mathrm{Cu}^{2+}$ had negative effect on the invertase activity from L. reuteri (Ginés et al. 2000) and from A. ochraceus (Guimarães et al. 2007). The presence of ions in the protein solution could affect the $\mathrm{pH}$, but it is known that the ions in solutions can interact with the charged amino acid groups in the protein (Kunz, 2006). This interaction may modify the conformational structure of the enzyme, or the ion may act directly on the active site, affecting the interaction with the substrate. Inhibition by $\mathrm{Hg}^{2+}$ is a signal of the presence thiol groups in the enzyme structure, important for its activity. Interestingly, FFase II showed around $67 \%$ of activity in the presence of $1 \mathrm{mM} \mathrm{Hg}^{+2}$, despite most enzymes are drastically inhibited by this ion.

\section{Circular dichroism}

The secondary structure of the purified $\beta$-D-fructofuranosidase II was evaluated by circular dichroism (Figure 6). The far ultraviolet spectrum of the purified protein shows a negative minimum at $205 \mathrm{~nm}$ and a shoulder at $216 \mathrm{~nm}$. The features of the spectra indicate that the purified protein presents a high contribution of random and $\beta$-sheet structures in the secondary structure. This result indicates that the purification procedure maintained the secondary native structure of the protein. In addition, the 
fructofuranosidases from yeast Xanthophylomices dendrorhous (Linde et al. 2009) and from Arabidopsis thaliana (Verhaest et al. 2006) have propeller and $\beta$-sheet motifs, as verified for the enzyme from $A$. phoenicis. These characteristics are found in many glycoside hydrolases from $\mathrm{GH} 32$ family, which includes $\beta$-D-fructofuranosidases.
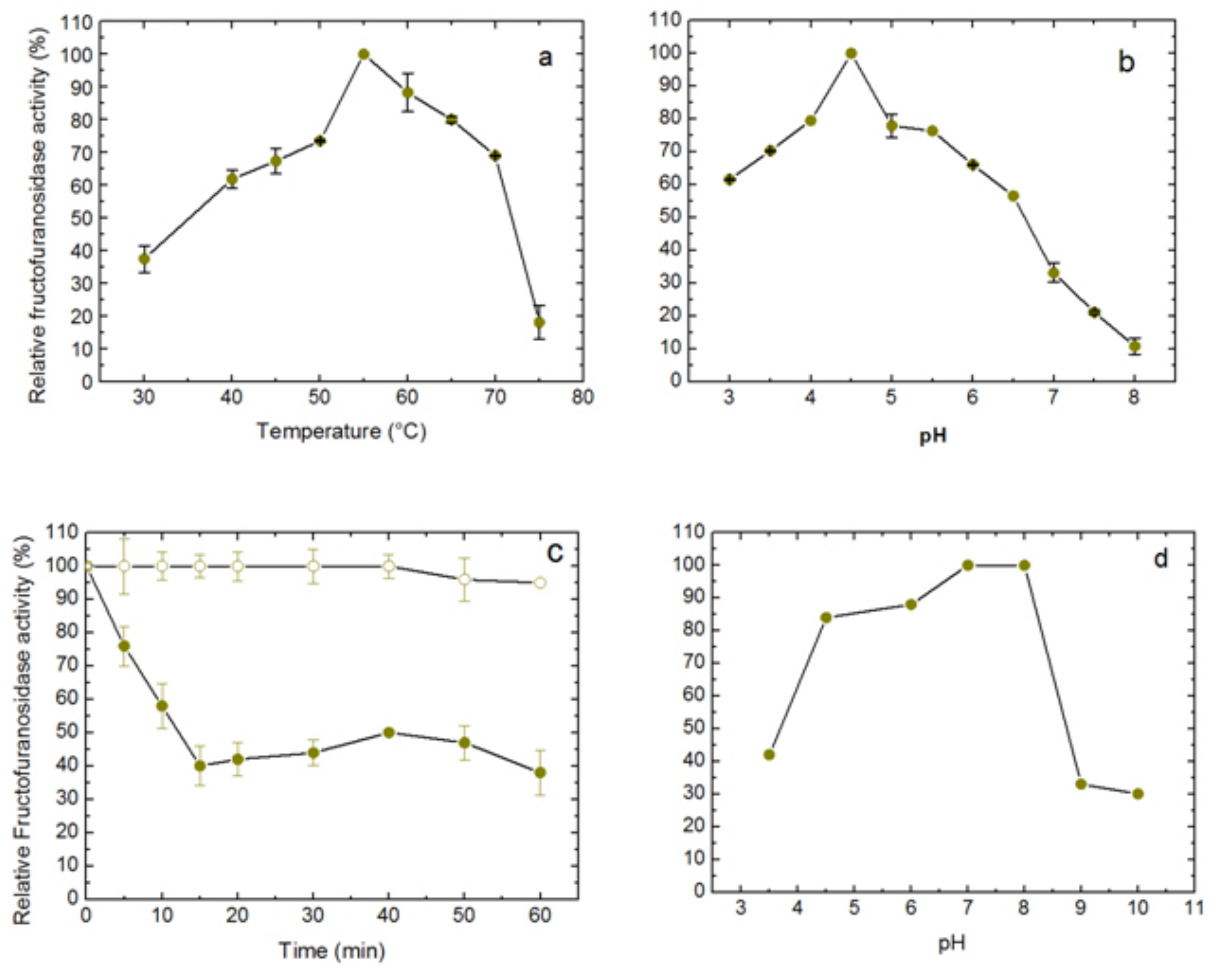

Fig. 4 Optima of temperature (a) and pH (b), thermal stability (c) at $50^{\circ} \mathrm{C}(\mathrm{)})$ and $60^{\circ} \mathrm{C}(\bullet)$, and pH stability (d) for the FFase II produced by $A$. phoenicis in SSF with soy bran as substrate.

\section{Enzyme specificity and kinetic parameters}

FFase II from A. phoenicis was able to hydrolyze sucrose, inulin and raffinose (Table 4). The values of activity obtained with substrate mixtures did not correspond to the hypothetical sum of the values obtained when each substrate was tested separately, suggesting that these substrates are hydrolyzed at the same active site. The analysis by TLC showed only the products of hydrolysis glucose and fructose after $24 \mathrm{hrs}$ of reaction at $60^{\circ} \mathrm{C}$, using $20 \%$ sucrose as substrate (data not shown). It has been cited that at low concentration of sucrose the hydrolytic activity is fostered and the fructosyltransferase activity could be observed at high concentration of sucrose (Chen and Liu, 1996). Under that condition, many fructofuranosidases exhibit fructosyltransferase activity being able to produce fructooligosacharides (FOS), as for instance the enzymes from Aspergillus sp. 27H (Fernández et al.

Table 4. Specificity of $\beta$-fructofuranosidase produced by $A$. phoenicis under SSF.

\begin{tabular}{cc}
\hline Substrates & Fructofuranosidase activity (U/g) \\
Sucrose & $306.54 \pm 6.32$ \\
Inulin & $53.76 \pm 1.66$ \\
Raffinose & $73.13 \pm 1.66$ \\
Sucrose + Inulin & $229.40 \pm 1.00$ \\
Sucrose + Raffinose & $290.00 \pm 8.98$ \\
Inulin + Raffinose & $51.60 \pm 2.00$ \\
\hline
\end{tabular}

Data are the means $\pm S D$ of at least 3 different experiments. 
2004) and A. niger IMI 303386 (Nguyen et al. 2005). However, the FFase II produced by A. phoenicis in SSF had no fructosyltransferase activity. On the other hand, this characteristic permits the use of the enzyme in the production of invert sugar using high concentration of sucrose, increasing the recovery of product. The kinetic parameters $\mathrm{K}_{\mathrm{m}}$ and $\mathrm{V}_{\max }$ obtained with sucrose were $18.6 \mathrm{mM}$ and $189.2 \mathrm{U} / \mathrm{mg}$ protein, with catalytic efficiency of $10 \mathrm{U} / \mathrm{mg} \mathrm{mM}^{-1}$. The $\beta$-D-fructofuranosidase II from $A$. phoenicis exhibited higher affinity for sucrose than the $\beta$-fructofuranosidase I from Aureobasidium pullulans DSM $2404\left(\mathrm{~K}_{\mathrm{m}}\right.$ of $\left.230 \mathrm{mM}\right)$ and the fructofuranosidases from A. niger ATCC $20611\left(\mathrm{~K}_{\mathrm{m}}\right.$ of $\left.290 \mathrm{mM}\right)$ and Aureobasidium sp. ATCC 20524 ( $\mathrm{K}_{\mathrm{m}}$ of $470 \mathrm{mM}$ ) (Nguyen et al. 2005).

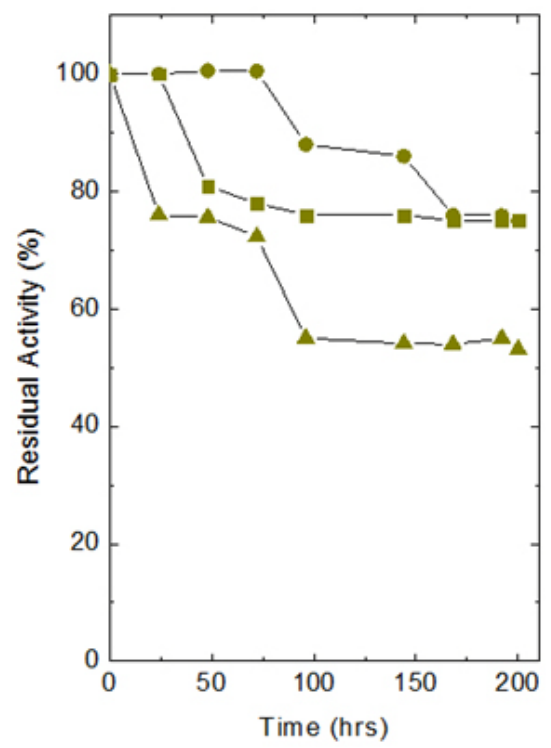

Fig. 5 Influence of the conditions of storage at $-20^{\circ} \mathrm{C}(\square), 4^{\circ} \mathrm{C}(\bullet)$ and $27^{\circ} \mathrm{C}(\Delta)$ on the FFase II activity from $A$. phoenicis.

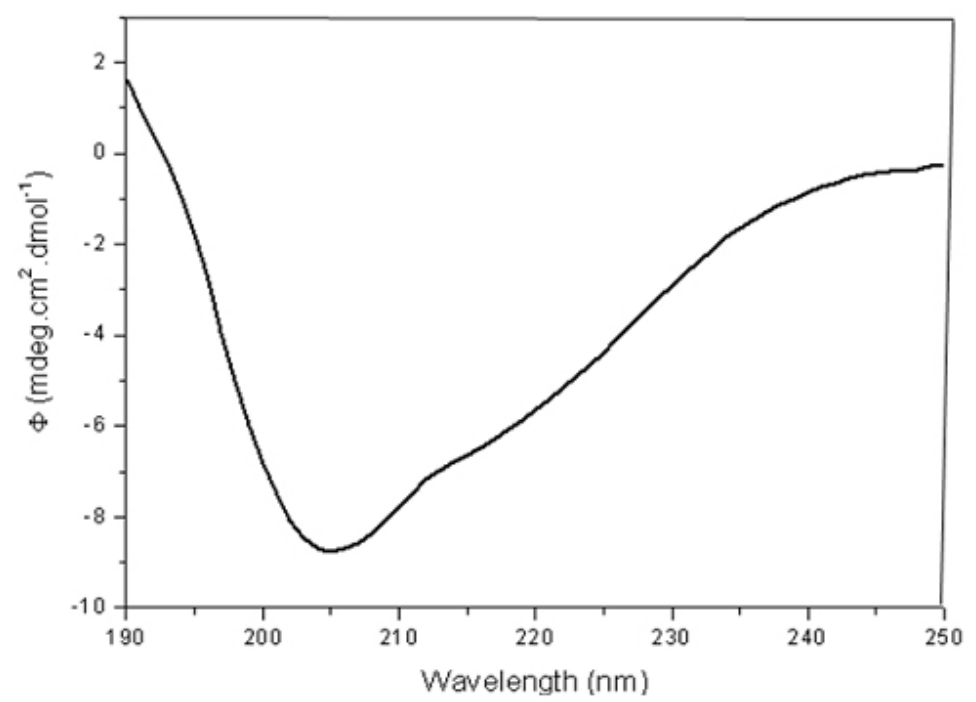

Fig. 6 Far-UV CD spectra of native purified $\beta$-D-fructofuranosidase II from $A$. phoenicis. The protein concentration used in the $C D$ experiments was $500 \mathrm{\mu g} \mathrm{mL}^{-1}$. See the Materials and Methods section for further details. 


\section{CONCLUDING REMARKS}

A. phoenicis produced two types of $\beta$-fructofuranosidase when cultured in SSF using an agroindustrial product as carbon source, what is very interesting for industrial application. The FFase II was a typical enzyme from the GH32 family, and exhibited properties that could justify its use for industrial production of invert sugar associated with the low cost of the carbon source/substrate, high affinity for sucrose, added to good thermal and storage stabilities.

\section{ACKNOWLEDGMENTS}

We thank Prof. Dr. Richard J. Ward for access to the Jasco 810 spectropolarimeter and Maurício de Oliveira for technical assistance.

Financial support: This work was supported by Fundação de Amparo à Pesquisa do Estado de São Paulo (FAPESP) and Conselho Nacional de Desenvolvimento Científico e Tecnológico (CNPq).

\section{REFERENCES}

ALBERTO, F.; BIGNON, C.; SULZENBACHER, G.; HENRISSAT, B. and CZJZEK, M. (2004). The threedimensional structure of invertase ( $\beta$-fructosidase) from Thermotoga maritima reveals a bimodular arrangement and an evolutionary relationship between retaining and inverting glycosidases. The Journal of Biological Chemistry, vol. 279, p. 18903-18910. [CrossRef]

ALMEIDA, A.C.S.; ARAÚJO, L.C.; COSTA, A.M.; ABREU, C.A.M.; LIMA, M.A.G.A. and PALHA, M.L.A.P.F. (2005). Sucrose hydrolysis catalyzed by auto-immobilized invertase into intact cells of Cladosporium cladosporioides. Electronic Journal of Biotechnology, vol. 8, no. 1. [CrossRef]

ARANDA, C.; ROBLEDO, A.; LOERA, O.; CONTRERAS-ESQUIVEL, J.C.; RODRIGUEZ, R. and AGUILAR, C.N. (2006). Fungal invertase expression in solid-state fermentation. Food Technology and Biotechnology, vol. 44, no. 2, p. 229-233.

ASHOKKUMAR, B.; KAYALVIZHI, N. and GUNASEKARAN, P. (2001). Optimization of media for $\beta-$ fructofuranosidase production by Aspergillus niger in submerged and solid state fermentation. Process Biochemistry, vol. 37, no. 4, p. 331-338. [CrossRef]

BHATTI, H.N.; ASGHER, M.; ABBAS, A.; NAWAZ, R. and SHEIKH, M.A. (2006). Studies on kinetics and thermostability of a novel acid invertase from Fusarium solani. Journal of Agriculture and Food Chemistry, vol. 54, no. 13, p. 4617-4623. [CrossRef]

BLUM, H.; BEIER, H. and GROSS, H.J. (1987). Improved silver staining of plant proteins, RNA and DNA in polyacrylamide gels. Electrophoresis, vol. 8, no. 2, p. 93-99. [CrossRef]

CHEN, W.C. and LIU, C.H. (1996). Production of $\beta$-fructofuranosidase by Aspergillus japonicus. Enzyme Microbial and Technology, vol. 18, no. 2, p. 153-160. [CrossRef]

CHENG, T.-C.; DUAN, K.-J. and SHEU, D.-C. (2005). Immobilization of $\beta$-fructofuranosidase from Aspergillus japonicus on chitosan using tris(hydroxymethyl)phosphine or glutaraldehyde as a coupling agent. Biotechnology Letters, vol. 27, no. 5, p. 335-338. [CrossRef]

DUBOIS, M.; GILLES, K.; HAMILTON, J.; REBERS, P. and SMITH, F. (1956). Colorimetric method for determination of sugars and related substances. Analytical Chemistry, vol. 28, no. 3, p. 350-356. [CrossRef]

FERNÁNDEZ, R.C.; MARESMA, B.G.; JUÁREZ, A. and MARTINEZ, J. (2004). Production of fructooligosaccharides by $\beta$-fructofuranosidase from Aspergillus sp $27 \mathrm{H}$. Journal of Chemical Technology and Biotechnology, vol. 79, no. 3, p. 268-272. [CrossRef]

GINÉS, S.C.; MALDONADO, M.C. and VALDEZ, G.F. (2000). Purification and characterization of invertase from Lactobacillus reuteri CRL 1100. Current Microbiology, vol. 40, no. 3, p. 181-184. [CrossRef]

GUIMARÃES, L.H.S.; TERENZI, H.F.; POLIZELI, M.L.T.M. and JORGE, J.A. (2007). Production and characterization of a thermostable extracellular $\beta$-D-fructofuranosidase produced by Aspergillus ochraceus with agroindustrial residues as carbon sources. Enzyme and Microbial Technology, vol. 42, no. 1, p. 52-57. [CrossRef]

GUIMARÃES, L.H.S.; SOMERA, A.F.; TERENZI, H.F.; POLIZELI, M.L.T.M. and JORGE, J.A. (2009). Production of $\beta$-fructofuranosidases by Aspergillus niveus using agroindustrial residues as carbon sources: Characterization of an intracellular enzyme accumulated in the presence of glucose. Process Biochemistry, vol. 44, no. 2, p. 237-241. [CrossRef]

KHANNA, P.; SUNDARI, S.S. and KUMAR, N.J. (1995). Production, isolation and partial purification of xylanases from an Aspergillus sp. World Journal of Microbiology and Biotechnology, vol. 11, no. 2, p. 242-243. [CrossRef]

KUNZ, W. (2006). Specific ion effects in liquids, in biological systems, and at interfaces. Pure and Applied Chemistry, vol. 78, no. 8, p. 1611-1617. [CrossRef] 
KURAKAKE, M.; OGAWA, K.; SUGIE, M.; TAKEMURA, A.; SUGIURA, K. and KOMAKI, T. (2008). Two types of $\beta$ fructofuranosidases from Aspergillus oryzae KB. Journal of Agricultural and Food Chemistry, vol. 56, no. 2, p. 591-596. [CrossRef]

LAEMMLI, U.K. (1970). Cleavage of structural proteins during the assembly of the head of bacteriophage T4. Nature, vol. 227, p. 680-685. [CrossRef]

LEONE, F.A.; BARANAUSKAS, J.A. and CIANCAGLINI, P. (1995). ENZYPLOT: A microcomputer assisted program for teaching enzyme kinetics. Biochemical Education, vol. 23, no. 1, p. 35-37. [CrossRef]

LINDE, D.; MACIAS, I.; FERNÁNDEZ-ARROJO, L.; PLOU, F.J.; JIMÉNEZ, A. and FERNÁNDEZ-LOBATO, M. (2009). Molecular and biochemical characterization of a $\beta$-fructofuranosidase from Xanthophyllomyces dendrorhous. Applied and Environment Microbiology, vol. 75, no. 4, p. 1065-1073. [CrossRef]

LOWRY, O.H.; ROSEBROUGH, N.J.; FARR, A.L. and RANDALL, R.J. (1951). Protein measurement with the folin phenol reagent. Journal of Biological Chemistry, vol. 193, p. 265-275.

MAIORANO, A.E.; PICCOLI, R.M.; SILVA, E.S. and RODRIGUES, M.F.A. (2008). Microbial production of fructosyltransferases for synthesis of pre-biotics. Biotechnology Letters, vol. 30, no. 11, p. 1867-1877. [CrossRef]

MILLER, G.L. (1959). Use of dinitrosalicylic acid reagent for determination of reducing sugar. Analytical Chemistry, vol. 31, no. 3, p. 426-428. [CrossRef]

NGUYEN, Q.D.; REZESSY-SZABÓ, J.M.; BHAT, M.K. and HOSCHKE, A. (2005). Purification and some properties of $\beta$-fructofuranosidase from Aspergillus niger IMI303386. Process Biochemistry, vol. 40, no. 7, p. 2461-2466. [CrossRef]

RIZZATTI, A.C.S.; JORGE, J.A.; TERENZI, H.F.; RECHIA, C.G.V. and POLIZELI, M.L.T.M. (2001). Purification and properties of a thermostable extracellular $\beta$-D-xylosidase produced by thermotolerant Aspergillus phoenicis. Journal of Industrial Microbiology and Biotechnology, vol. 26, no. 3, p. 156-160. [CrossRef]

ROMERO-GÓMEZ, S.; AUGUR, C. and VINIEGRA-GONZÁLEZ, G. (2000). Invertase production by Aspergillus niger in submerged and solid-state fermentation. Biotechnology Letters, vol. 22, no. 15, p. 1255-1258. [CrossRef]

RUBIO, M.C.; RUNCO, R. and NAVARRO, A.R. (2002). Invertase from a strain of Rhodotorula glutinis. Phytochemistry, vol. 61, no. 6, p. 605-609. [CrossRef]

RUBIO, M.C. and NAVARRO, A.R. (2006). Regulation of invertase synthesis in Aspergillus niger. Enzyme and Microbial Technology, vol. 39, no. 4, p. 601-606. [CrossRef]

RUSTIGUEL, C.B.; TERENZI, H.F.; JORGE, J.A. and GUIMARÃES, L.H.S. (2010). A novel silver-activated extracellular $\beta$-D-fructofuranosidase from Aspergillus phoenicis. Journal of Molecular Catalysis B: Enzymatic, vol. 67, no. 1-2, p. 10-15. [CrossRef]

TOLEDO, L.E.T.; RIERA, R.R.; CASTILLO, A.B.; ROMERO, M.S.; SOSA, J.G.A. and GARCÍA, L.H. (2004). Catalytical properties of $\mathrm{N}$-glycosylated Gluconacetobacter diazotrophicus levansucrase produced in yeast. Electronic Journal of Biotechnology, vol. 7, no. 2. [CrossRef]

VERHAEST, M.; LAMMENS, W.; LE ROY, K.; DE CONINCK, B.; DE RANTER, C.J.; VAN LAERE, A.; VAN DEN ENDE, W. and RABIJNS, A. (2006). X-ray diffraction structure of a cell-wall invertase from Arabidopsis thaliana. Acta Crystallographica Section D, Biological Crystallography, vol. 62, no. 12, p. 1555-1563. [CrossRef]

VOGEL, H.F. (1964). Distribution of lysine pathways among fungi: Evolutionary implications. The American Naturalist, vol. 98, p. 435-446. [CrossRef]

WARCHOL, M.; PERRIN, S.; GRILL, J.P. and SCHNEIDER, F. (2002). Characterization of a purified $\beta$ fructofuranosidase from Bifidobacterium infantis ATCC 15697. Letters in Applied Microbiology, vol. 35, no. 6, p. 462-467. [CrossRef]

YOSHIKAWA, J.; AMACHI, S.; SHINOYAMA, H. and FUJII, T. (2006). Multiple $\beta$-fructofuranosidases by Aureobasidium pullulans DSM2404 and their roles in fructooligosaccharide production. FEMS Microbiology Letters, vol. 265, no. 2, p. 159-163. [CrossRef]

YOSHIKAWA, J.; AMACHI, S.; SHINOYAMA, H. and FUJII, T. (2007). Purification and some properties of $\beta$ fructofuranosidase | formed by Aureobasidium pullulans DSM 2404. Journal of Bioscience and Bioengineering, vol. 103, no. 5, p. 491-493. [CrossRef]

\section{How to cite this article:}

RUSTIGUEL, C.B.; DE OLIVEIRA, A.H.C.; TERENZI, H.F.; JORGE, J.A. and GUIMARÃES, L.H.S. (2011). Biochemical properties of an extracellular $\beta$-D-fructofuranosidase II produced by Aspergillus phoenicis under solid-sate fermentation using soy bran as substrate. Electronic Journal of Biotechnology, vol. 14, no. 2. http://dx.doi.org/10.2225/vol14-issue2-fulltext-1 